\title{
Pengajaran Daring untuk Meningkatkan Partisipasi Siswa dan Ketuntasan Belajar pada Mata Pelajaran Biologi di SMAdengan Platform Google Classroom
}

\author{
Sriwiyati \\ ${ }^{1}$ SMA N 2 Tarakan \\ * Corresponding Author. E-mail: swiyati.bio@gmail.com
}

Receive: $10 / 01 / 2021$

Accepted:03/02/2021

Published: 01/03/2021

\begin{abstract}
Abstrak
Tujuan utama penelitian ini untuk meningkatkan prosentase ketuntasan belajar Biologi dengan memanfaatkan platform Google Classroom(GC). Subjek penelitian ini adalah siswakelas XI MIPA 5 SMA Negeri 2 Tarakan. Mereka berjumlah 35 siswa, 16 laki-laki dan 19 perempuan. Penelitian ini dilaksanakan dalamduasiklus; masing-masing tigakali pertemuan. Pengumpulan data dilakukan melalui tes, observasi, dan dokumentasi. Hasilpenelitian membuktikanbahwaaplikasi GC dapat meningkatkan hasil belajar siswa, yang dibuktikan dengan hasil belajar di setiapaspek pengamatan dan tindakan yang mengalami peningkatkan. Hal tersebut juga tampak dari peningkatan hasil belajar siswadi setiap siklus dan setiap akhir pertemuan mengajar. Hasil belajar siswa menunjukkan peningkatan yang semula 37,1 pada siklusImenjadi $66,7 \%$ pada siklus II, dengan kehadiran siswa $98,1 \%$ pada siklus I meningkat menjadi 100,0\% pada siklus II. Dengan ketuntasan $70 \%$ dan rata-rata nilai 67,1 maka penelitian dihentikan walaupun masih terdapat 10 siswa atau $28,6 \%$ yang belum tuntas maka akan diberikan remedial tersendiri dalam waktu yang berbeda sehingga semua siswa kelas XI MIPA 5 ini diharapkan akan memperoleh ketuntasan pembelajaran.Dengan demikian, pembelajaran menggunakan aplikasi Google Classroomterbukti dapat meningkatkan hasil belajar siswa.
\end{abstract}

Kata Kunci: hasil belajar, partisipasi, pembelajaran daring, Google Classroom.

\begin{abstract}
The purpose of this study is to improve learning outcomes for Biology subject in highschool using the Google Classroom application. The subjects of this study were 35 students of class XI MIPA 5 SMA Negeri 2 Tarakan, consisting of 16 male and 19 female students. This research was conducted in two cycles with three meetings in each. The data collection was carried out through tests, observation and documentation. The result of the study has proved that GC can improve student learning outcomes, as evidenced by the learning outcomes. This can also be seen from the increase in student learning outcomes in each cycle and at the end of each meeting. Their learning outcomes showed an increase from $37.1 \%$ in the first cycle to $66.7 \%$ in the second, with a $98.1 \%$ student attendance in the first, and increasing to $100.0 \%$ in the second cycle. With $70 \%$ completeness and an average score of 67.1 , this action research is decided to be enough. There were still 10 students or $28.6 \%$ who have not reached the learning completion. For them, a separate remedial will be given at different times so that all the students are expected to get a complete learning. Thus, learning using the Google Classroom application is proven to improve the student learning outcomes.
\end{abstract}

Keywords: learning outcomes, participation, online learning, Google Classroom. 


\section{Pendahuluan}

Materi Sistem Organ bagi siswa SMA pada umumnya merupakan pelajaran yang sulit dipahami, karena obyek kajiannya yang bersifat abstraks. Akibatnya para siswa menemukan permasalahan yang kompleks dan rumit bagi mereka. Mereka mengalami kebingungan dan kesulitan untuk menguasai konsep Sistem Organ (Nova:2018, lihat juga Nenden: 2015). Hal ini terbukti dari hasil dari pembelajaran mereka, yang memperlihatkan nilai yang kurang memuaskan.

Untuk mengatasi permasalahan tersebut, seorang guru Biologi harus berupaya membuat para siswa terlibat dalam proses pembelajaran. Untuk tujuan itu, guru harus menumbuhkan situasi pembelajaran yang "asyik" dan menyenangkan. Kegiatan pembelajaran semacam ini dapat hadir bila guru menerapkan metode pembelajaran yang variatif denganmenggunakan media pembelajaran yang relevan dan inovatif.Kombinasi metode dan media yang positif tersebut berfungsi menarik minat, memperkuat kognitif siswa dan menumbuhkan kebermaknaan pembelajaran. Pada akhirnya, siswa diharapkan memahami dan menguasai konsep materi secara optimal (Heri: 2020).

Harapan menghadirkan pembelajaran yang menarik untuk menyampaikan konsep abstrak ini terhalang oleh pecahnya wabah sedunia, pandemi. Penyebaran Corona Virus Disease (COVID-19) membawa pengaruh yang signifikan yang berakibat pada kegiatan proses belajar mengajar di sekolah. Kegiatan belajar mengajar beralih di rumah, dengan sistem Pembelajaran Jarak Jauh (PJJ) dalam kelas maya (Sevima: 2020, Fitra dkk:2020).

Untungnya kemajuan teknologi IT sepertinya ada untuk menjadi jawaban situasi pandemi, meskipun sebenarnya teknologi tersebut sudah ada jauh sebelum wabah mendunia ini terjadi. Sebenarnya banyak aplikasi yang bisa dimanfaatkan untuk pembelajaran daring, tetapi para guru, termasuk peneliti, kurang memperoleh informasi dan tidak dilatih untuk mengajar dengan memanfaatkan teknologi atau pun aplikasi baik melalui telepon seluler atau pun komputer/laptop (Anugerah, 2020; Sevima, 2020, Soni dkk., 2018). Mereka akhirnya sekedar menggunakan aplikasi yang lazim digunakan dalam komunikasi sehari-hari, yakni media sosial Whatsapp, dengan memanfaatkan fitur Group. Melalui grup WA, komunikasi dilakukan dengan bahasa tulis atau pun voice note, yakni dengan merekam dan mengirimkan apa yang hendak disampaikan. Dengan perangkat ini, peneliti biasanya memberikan materi dalam bentuk PPT yang mencakup keseluruhan topik, disertai dengan video pembelajaran noninteraktif. Di akhir, siswa langsung diberi tugasyang berhubungan dengan materi tersebut (Farhana, 2020; Sevima, 2020).

Sayangnya, pembelajaran daring dengan media sosial ini kurang berhasil. Hal ini tampak dari respon siswa yang tidak maksimal baik dalam pemahaman konsep atau pun pengumpulan tugas.Dalam proses pembelajaran, sangat sedikit siswa yang mengajukan pertanyaan. Aktifitas belajar siswa cenderung rendah ditandai dengan sedikitnya siswa yang mengisi presensi tepat waktu, pasif selama pemebelajaran dan tidak responsif atau lambat dalam menyelesaikan tugas sekolah.

Di akhir pembelajaran, banyak siswa yang tidak tuntas ketika diadakan tes hasil belajar. Hasil tes pra-tindakan di kelas XI MIPA 5 SMAN Negeri 2 Tarakan, hasil belajar dari para siswa dapat dikategorikan rendah, dengan nilai rata-rata hanya sebesar 56,3. Dari 35 siswa, hanya25,7 \% yang dapat mencapai nilai KKM, yakni 70. Hasil ini dapat diprediksi dari proses belajar yang berlangsung sebelumnya.

Faktor dari kegagalan pembelajaran tersebut sangat beragam di lapangan. Banyak kendala teknis yang menghambat pembelajaranseperti gangguan atau fasilitas jaringan internet yang kurang mendukung, tipetelepon seluler yang tidak supportatau bahkan ketiadaan telepon seluler ataupun komputer/laptop. Selain faktor terknis tersebut, masalah lain adalah kurangnya pengawasan orang tua; para siswa tidak mengikuti mata pelajaran sesuai jadwal yang ada. Di sisi guru, beberapa kendala juga muncul: kurang terampil menggunakan 
aplikasi (Fitra dkk, 2020), kurang inovatif dalam meramu materi dari konvesional ke daring, dan pemahaman aplikasi edukasi yang sesuai dengan materi serta metode yang diterapkan(lihat Nenden, 2015; Anugerah, 2020; Soni dkk., 2018).

Karena itu, peneliti merasa perlu melakukan tindakan perubahan untuk meningkatkan kualitas dan hasil pembelajaran. Peneliti menggunakan aplikasi Google Classroom(selanjutnya, GC) sebagai platform pembelajaran pembelajaran daring. Tujuan utamanya adalah agar siswa dapat memperoleh materi yang lebih banyak dan beragam, yang berupa video pembelajaran tetapi dengan intensitas yang lebih banyak yakni per sub-pokok bahasan (lihat Soni dkk, 2018; Gunawan dan Sunarman, 2017). Selain itu, mereka juga mendapatkan video presentasi power pointyang berisi penjelasan konsep-konsep penting dalam video. Selain itumereka diberikan tugas melalui lembar kegiatan siswa (LKS) secara terstruktur (Anonim, 2020).

\section{Metode Penelitian}

Penelitian ini mengadopsi metode penelitian tindakan kelas, yang bertujuan untuk meningkatkan kualitas pembelajaran. Peneliti ini dilakukan karena seorang guru merasa ada hal yang kurang atau bermasalah dalam pembelajaran di kelasnya. Untuk itulah guru kemudian menerapkan langkah-langkah untuk mengatasi masalah tersebut. Tahapan PTK meliputi 4 hal, yakni perencanaan, pelaksanaan, pengamatan, dan refleksi, yang bersifat siklis atau dapat diulang untuk mencapai pemecahan masalah dan hasil yang maksimal (Arikunto, 2011, lihat juga Anugerah, 2020). Bila dicermati, tahap pengamatan tentunya lebih bersifat mengiringi "pelaksanaan", dan umumnya prosedur ini dilakukan oleh teman/mitra peneliti. Sementara peneliti, sebagai guru, harus menerapkan strategi perbaikan yang telah direncanakan. Gambaran pelaksanaan PTK dapat diamati pada Bagan 1.

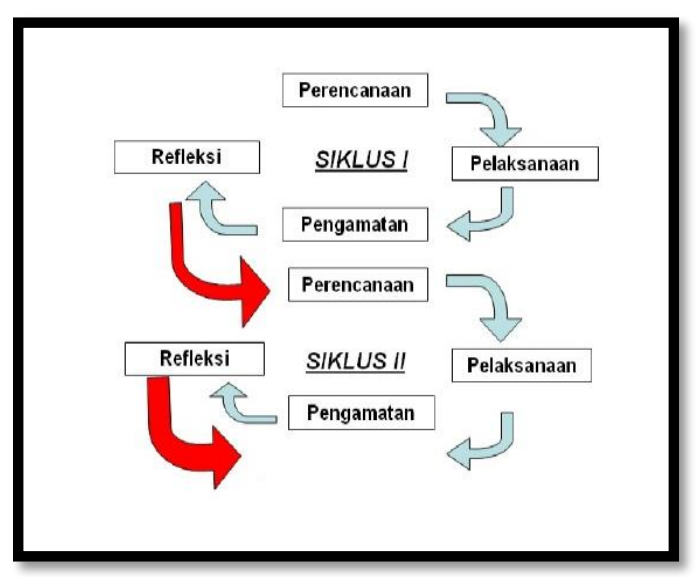

Bagan 1 Siklus PTK (Suharsimi: 2011)

PTK dilaksanakan di SMA Negeri 2 Tarakan, pada semester ganjil 2020/2021, dari Oktober sampai dengan Desember 2020. Adapun materi yang disampaikan dalam pembelajaran adalah mata pelajaran Biologi dengan kompetensi dasar "Menganalisis hubungan antara struktur jaringan penyusun organ pada Sistem Gerak dan Sistem Peredaran Darah manusia dalam kaitannya dengan bioproses dan gangguan fungsi yang dapat terjadi pada Sistem Gerak dan Sistem Peredaran Darah manusia" (Nova: 2018). Pelaksanaan tindakan dilakukan pada tiga minggu pertama bulan Oktober untuk siklus I, dan minggu pertama November; masing-masing siklus ditempuh dengan tiga pertemuan daring. Subjek dari PTK ini adalah siswa kelas XI MIPA5 di SMA Negeri 2 Tarakan. Mereka berjumlah 35 orang, terdiri dari 16 laki-laki dan 19 perempuan. PTK ini menggunakan beberapa teknik pengumpulan data, yaitu observasi, tes, dan dokumentasi (Basir, 1988). Teknikteknik tersebut dimaksudkan untuk menjaring informasi yang benar dan akurat untuk mencapai tujuan penyelesaian masalah di kelas daring.

\section{Temuan dan Pembahasan}

Pada bagian ini akan dipaparkan pelaksanaan tindakan yang dilakukan pada siswa kelas sebagai subjek kajian. Sebagaimana dipaparkan sebelumnya, PTK 
Jurnal Edumaspul, 5 (1), Year 2020 - 3

(Sriwiyati )

diwujudkan dalam 4 tahapan, perencanaan, pelaksanaan, pengamatan, dan refleksi (Arikunto, 2011). Tahap-tahap yang sudah dilaksanakan tersebut dipaparkan dan disertai dengan hasil-hasil yang dicapai dari tiap siklus. Di bagian akhir, dilakukan pembahasan khususnya terkait hasil perbaikan yang dilakukan.

\section{Pelaksanaan Tindakan Kelas}

Pelaksanaan tindakan dalam PTK mencakup 4 tahap, yang dijelaskan implementasinya dalam kajian ini. Deskripsi ini bersifat general untuk merangkum tahapan-tahapan yang dilaksanakan pada tiap pertemuan dari kedua siklus dalam PTK ini.

\section{1) Perencanaan (Planning)}

Perencanaan pertemuan dilakukan dengan menimbang permasalahan yang muncul sebelumnya. Tujuannya agar di pertemuan berikutnya, permasalahan tersebut dapat diatasi. Dari hasil uji, masalah utama adalah pemahaman siswa yang masih belum optimal. Untuk mengatasi hal itu, langkah-langkah berikut ditempuh dalam tahap perencanaan.

a) Mempersiapkan materi ( video noninteraktif)

b) Merevisi RPP

c) Membuat instrumen observasi aktivitas siswa dan guru.

d) Membuat instrumen evaluasi berupa LKS

e) Merevisi soal tes akhir

f) Membuat absensi online di Google Form

\section{2) Pelaksanaan (Acting)}

Siklus Idilakukan pada tanggal 13, 20, 27 Oktober 2020, dan siklus II dilaksanakan pada 2, 3 dan 16 November 2020. Tiap pertemuan berlangsung dalam 2 jam pelajaran (2 x 30 menit). Aktivitas pembelajaran dilakukan berdasarkan RPP, dengan menggunakan Google Classroom, dengan media pembelajaran video pembelajaran noninteraktif, yang diunggah pada platform tersebut.
Penerapan diawali dengan memberikan salam di WhassApp Group menanyakan bagaimana keadaan siswa apakah baik-baik saja, dan berdo'a bersama sebelum memulai pembelajaran. Kemudian guru memberikan link absen yang dibuat diGoogle Form mempersilahkan siswa mengisi absen dan mengirimnya. Dan, guru menyuruh semua siswa membuka aplikasi Google Classroom.

Pembelajaran dimulai dengan menguji pengetahuan siswa dengan memberi pertanyaan apersepsi.Setelah itu, siswa diberikan motivasi agar mereka berminat dan semangat dalam belajar video atau gambar.Guru kemudian memberikan video pembelajaran noninteraktif. Sebelum siswa mempelajari materi video, guru memberikan arahan kepada siswa untuk mengamati, mencermati dan memahami video. Mereka diminta untuk merangkum isi materi tersebut. Lalu, guru membagikan LKS untuk dikerjakan oleh siswa dengan tenggat waktu tertentu. Setelah siswa mengumpulkan pekerjaan dari LKS, guru membahas dan membuat kesimpulan. Terakhir guru memberikan informasi mengenai rencana pembelajaran untuk pertemuan berikutnya.

Pada ujung pembelajaran, siswa diberikan tes evaluasi berupa 12 butir soal PG menggunakan Google Form. Siswa diberikan penjelasan tentang cara menjawab dan mengumpulkan tugas tersebut. Guru mengkonfirmasi pemahaman mereka dan membuka ruang diskusi untuk menampung pertanyaan yang muncul. Setelah dirasa cukup, pembelajaran ditutup dengan mengucapkan doa penutup bersama.

\section{3) Pengamatan (Observing)}

Pada tiap pertemuan, peneliti bertindak sebagai guru yang mempraktikkan RPP dan bertindak sebagai observer adalah teman guru yang bersama-sama memperhatikan aktifitas siswa selama kegiatan belajar mengajar.Hasil penelitian yang dilakukan oleh observer menggunakan instrumen lembar pengamatan aktivitas siswa dan lembar pengamatan aktivitas guru.

Hasil pengamatan aktivitas siswa yang lain adalah semangat siswa dalam mengikuti 
pelajaran masih rendah. Siswa masih belum antusis dalam mengikuti pembelajaran, terlihat masih sedikit siswa yang menjawab pertanyaan ketika guru memberi pertanyaan apersepsi.Selain itu masih banyak siswa yang terlambat mengumpulkan hasil LKS.Namun beberapa siswa mengikuti pembelajaran dengan baik.Karena penyelesaian LKS sedikit menyita banyak waktu sehingga menyebabkan distribusi waktu yang direncanakan dalam RPP tidak dapat dilaksanakan secara sempurna. Sedangkan hasil observasi aktifitas guru selama pembelajaran Biologi siklus I pertemuan 3 diketahui bahwa pembelajaran masih belum terlaksana secara maksimal. Guru masih belum dapat menerapkan RPP yang disusun secara sempurna.

\section{4) Refleksi (Reflecting) \\ Permasalahan utama pada akhir siklus} ladalah kurangnya semangat siswa mengikuti pembelajaran dan keaktifan mereka yang masih kurang memadai. Hanya sedikir dari mereka yang menjawab pertanyaan apersepsi guru dan mereka terlambat mengirimkan hasil LKS. Dari hasil tes akhir, masih banyak yang belum tuntas, bahkan mengalami kenaikan jumlah siswa yang belum tuntas. Untuk itu, solusi perbaikan yang dapat dilakukan berdasarkan hasil dari siklus I adalah:

a) Apersepsi dilakukan oleh guru dengan cara menguji pemahaman siswa dengan cara memberi pertanyaan tentang pengalaman belajar sebelumnya dengan lebih intensif lagi dan selalu berkomunikasi dengan siswa dengan memberikan tanggapan atas jawaban siswa, hal ini dilakukan supaya siswa merasa dihargai oleh gurunya. Siswa selalu diperingatkan untuk selalu aktif dengan memanggil nama siswa yang belum menjawab pertanyaan guru supaya siswa merasa diperhatikan oleh gurunya, sehingga mau menjawab pertanyaan guru.

b) Pada saat kegiatan inti setelah guru memberi video pembelajaran noninteraktif, siswa disuruh merangkum sendiri hasil pengamatan video . Tujuannya adalah agar siswa lebih mudah mengingat dan memahami materi yang ditayangkan di video pembelajaran noninteraktif.

c) Pada saat menyelesaikan LKS juga selalu diingatkan untuk menjawab dengan benar dan mengumpulkan hasilnya sesuai batas waktunya, di beri penjelasan bahwa yang cepat selesai akan mendapat nilai tambah, tujuannya adalah siswa lebih bersemangat sehingga siswa bisa menyelesaikannya tepat waktu.

d) Hasil belajar siswa pada tiapakhir pertemuan dicatat dan ditabulasi. Siswa yang tidak mengikuti tes akhir dikonfirmasikan ke orang tuanya melalui wali kelas, supaya menjadi perhatian orang tuanya. Mereka juga diberikan waktu untuk mengikuti tes susulan. Siswa yang belum tuntas diberikan remedial sebelum mengikuti KBM berikutnya.

\section{Hasil Tindakan dan Pembahasan}

Berikut ini merupakan pembahasan hasil penelitian tentang penggunaan aplikasi GC menggunakan media video pembelajaran noninteraktif dan video presentasi power point pada mata pelajaran Biologi kelas XI MIPA 5 Tarakan.

\section{Hasil Belajar Siswa}

Hasil belajar siswa setelah melaksanakan pembelajaran secara daring pada kedua siklus dapat dideskripsikan menjaditabel rekapitulasi seperti pada Tabel $1 .$.

\section{Tabel 1.Rekapitulasi Ketuntasan Belajar}

\begin{tabular}{lclll}
\hline Siklus & Pertemuan & $\mathrm{F}$ & $(\%)$ & Rerata \\
\hline I & 1 & 13 & 37,1 & 60,0 \\
& 2 & 9 & 25,7 & 52,3 \\
& 3 & 6 & 17,1 & 50,3 \\
II & 4 & 9 & 25,7 & 52,3 \\
& 5 & 16 & 45,7 & 54,6 \\
& 6 & 12 & 34,3 & 66,9 \\
\hline
\end{tabular}


Dengan memperhatikan Tabel 1, hasil belajar siswa terlihat mempunyai kecenderungan menurun dari pertemuan ke1 hingga pertemuan ke-3 dan naik pada pertemuan ke-4 hingga pertemuan ke-6 dengan asumsi sebagai berikut:

1) Pada awal pertemuan, siswa relatif masih baru masuk kelas XI, orang tua masih mampu membiayai pulsa data siswa sehingga siswa mampu mengikuti pembelajaran secara daring (online) dengan aktif.

2) Pada pertemuan berikutnya siswa mulai kesulitan mengikuti pembelajaran karena kondisi ekonomi keluarga semakin sulit, pekerjaan orangtua terbatas dan penghasilan orang tuapun semakin berkurang sehingga pulsa data anaknya sulit didapat.

3) Ada beberapa siswa Handphone (HP) androidnya rusak atau tidak supportsehingga tidak dapat mengikuti pembelajaran dengan baik

4) Ada beberapa siswa pada saat KBM berlangsung penggunaan Handpone (HP) bergantian dengan saudara yang lainnya yang juga berstatus sebagai pelajar sehingga tidak dapat mengikuti pembelajaran secara maksimal

5) Beberapa siswa hanya hadir untuk absensi namun tidak mengikuti pembelajaran secara maksimal, seperti tidak ikut tes akhir karena menjadi panita dalam kegiatan sekolah secara virtual atau disuruh orang tuanya.

6) Kondisi siswa yang tidak pernah bertemu guru secara langsung menyulitkan siswa belajar materi yang diajarkan guru melalui literasi dalam GC.

7) Pada pembelajaran selanjutnya yaitu mulai pembelajaran ke-4 hingga pembelajaran ke-6 siswa telah memperoleh bantuan paket data baik dari sekolah maupun dari pemerintah sehingga siswa lebih leluasa untuk mencari literature pembelajaran melalui internet, dan siswa lebih intensif dalam mengikuti pembelajaran online tanpa memikirkan lagi biaya untuk membeli paket data.

\section{Partisipasi Siswa}

Kehadiran siswa dalam pembelajaran secara daring (online), mata pelajaran Biologi di kelas XI MIPA 5 SMA Negeri 2 Tarakan pada siklus I, maka dapat dideskripsikan aktifitas kehadiran siswa tersebut kedalam rekapitulasi aktifitas kehadiran siswa pada siklus I seperti pada Tabel 4.16 ini.

Tabel 2. Rekapitulasi Aktifitas Kehadiran Siswa Siklus I

\begin{tabular}{lccl}
\hline Siklus & Pertemuan & $\mathrm{F}$ & $(\%)$ \\
\hline $\mathrm{I}$ & 1 & 33 & 94,3 \\
& 2 & 35 & 100,0 \\
& 3 & 35 & 100,0 \\
$\mathrm{II}$ & 4 & 35 & 100,0 \\
& 5 & 35 & 100,0 \\
& 6 & 35 & 100,0 \\
\hline
\end{tabular}

Dengan memperhatikan Tabel 2, hasil keaktifan kehadiran siswa mempunyai kecenderungan meningkat dari pertemuan 1 ke pertemuan 2 , bahkan sampai pertemuan ke-6 siswa selalu hadir $100 \%$. Pada awal pembelajaran terjadi permasalahan kehadiran pada beberapa siswa, namun bisa diatasi dengan melakukan pendekatan kepada siswa, sehingga pada pertemuan berikutnya siswa selalu hadir. Hasil ini selaras dengan hasil kajian lain (Nirfayanti dan Nurbaeti, 2019), yang membuktikan penggunaan GC berpengaruh signifikan bagi peningkatan motivasi belajar mahasiswa dalam Matakuliah Analisis Real 1.

\section{Aktivitas Guru Dalam Pembelajaran Daring (Online)}

Keaktifan guru dalam pembelajaran secara daring (online), senantiasa aktif melakukan tugas dan fungsinya.

Keaktifan guru dalam melaksanakan pembelajaran secara daring (online) mata pelajaran Biologi di kelas XI MIPA 5 SMA Negeri 2 Tarakan dapat dijelaskan dengan rincian kegiatan sebagai berikut: 
1) Pada awal tahun pelajaran, guru mulai mempersiapkan semua perangkat pembelajaran, bahan ajar dan media pembelajaran yang akan digunakan dalam pembelajaran berupa video pembelajaran, aplikasi $G C$ beserta dengan banyaknya kelas yang akan digunakan dalam pembelajaran Biologi.

2) Pada awal pertemuan relatif masih lancar dan semua siswa mengikuti pembelajaran online. Siswa dapat mengirimkan tugas juga tepat waktu dan guru mampu mengoreksi dan mengembalikan tugas siswanya namun pembelajaran berikutnya mengalami kendala terutama beberapa orang tua tidak mampu lagi membelikan pulsa data anaknya sehingga mereka tidak mengikuti pembelajaran.

3) Ada beberapa siswa mengalami kendala teknis seperti HP yang hilang atau tidak support. Siswa yang lain tidak memiliki akses penggunaan HP karena harus bergantian dengan saudaranya. Sebagian yang lain hanya hadir untuk absensi namun tidak mengikuti pembelajaran secara maksimal. Guru memfasilitasi siswa untuk dapat hadir disekolah untuk meminta tugas secara luring. Namun, tetap ada sebagian dari mereka yang mengalami kesulitan terutama yang bermasalah dengan HP. Untuk kelompok ini, guru memberikan pelayanan luring agar mereka dapat mengikuti pembelajaran.

Kegiatan pembelajaran menggunakan fasilitas $G C$ seperti mengalami penurunan terutama di awal pembelajaran. Namun, hasil belajar siswa setiap pertemuannya mengalami peningkatan. Hal ini tampak dari jumlah siswa yang mengikuti pembelajaran secara daring makin meningkat cukup signifikan. Begitu halnya, bila dicermati dari prosentase ketuntasan dan juga rerata nilai dari kelas tersebut.

Keberhasilan pengajaran dengan GC ini juga terbukti oleh Gunawan dan Sunarman (2017) dalam pengembangan keterampilan pemecahan masalah pada materi Vektor untuk siswa SMK. Hasil yang positif dari penggunaan GC di materi matematika juga dibuktikan oleh Nirfayanti dan Nurbaeti (2019), yang berhasil meningkatkan motivasi dan hasil belajar dari para subjek di kelasnya.

Selain itu, penggunaan GC juga terbukti cukup efektif untuk menggantikan kelas konvensional untuk siswa sekolah dasar (Salamah; 2020), dengan fitur yang komprehensif untuk penyampaian materi maupun pengumpulan tugas dengan kemasan yang fleksibel. Temuan serupa untuk siswa pada tingkat dasar juga disimpulkan oleh Wicaksono dan Rachmadayanti (2017), dalam konteks pembelajaran blended learning. Mereka mendapati bahwa GC berperan penting khususnya bagi kelas-kelas tinggi di SD untuk menciptakan situasi yang nyaman agar siswa secara aktif mengkonstruksi pengetahuan, tanpa terbatas di dalam ruang kelas. Temuan serupa juga disimpulkan oleh Hapsari dan Pamungkas (2019), dengan penerapan GC pada periode pra-pandemi dan diterapkan sebagai pembelajaran campuran (blended) dengan metode konvensional, tetapi pada konteks pendidikan di kampus. Lagi-lagi fleksibiltas dan ketidakterbatasan menjadi value yang penting dalam penggunaan platform ini sebagai ruang pembelajaran, sekaligus memupuk lierasi teknologi bagi para mahasiswa.

Dari hasil kajian ini, serta hasil positif dari kajian-kajian sebelumnya dalam berbagai konteks pendidikan, GC terbukti cukup handal sebagai media atau platform pembelajaran. Pemanfaatan secara optimal, dengan mendayagunakan semua fitur yang ada, seharusnya bisa menjadikan GC sebagai pengganti ruang kelas konvesional. Pekerjaan guru tinggal memahami secara komprehensif platform tersebut, sehingga pelaksanaan pembelajaran dapat berjalan secara efektif dan efisien.

\section{Kesimpulan}

Berdasarkan hasil analisis, dapat disimpulkan bahwa penggunaan GC dengan materi video yang rinci dapat meningkatkan prosentase ketuntasan belajar siswa. Hal ini tampak dari hasil pembelajaran materi pokok Sistem Organ dengan peningkatan yang cukup besar, dari $37,1 \%$ pada siklus I 
menjadi $66,7 \%$ pada siklus II. Peningkatan tersebut juga terjadi pada tingkat partisipasi mereka, dari siklus I dengan 98,1\% menjadi $100,0 \%$ pada siklus II. Dengan memperhatikan hasil penelitian dengan ketuntasan $70 \%$ dan rata-rata nilai 67,1 maka penelitian dihentikan walaupun masih terdapat 10 siswa atau 28,6\% yang belum tuntas maka akan diberikan remedial tersendiri dalam waktu yang berbeda sehingga semua siswa tuntas dalam pembelajaran.

\section{Daftar Pustaka}

Anonim. 2020. Mengenal Apa itu Google Classroom : Fitur, Fungsi, dan Keunggulannya dalam Serba Serbi Technology.

https://idcloudhost.com/mengenal-apaitu-google-classroom-fitur-fungsi-dankeunggulannya/, dibuka tanggal 29 Oktober 2020 pukul 20.05 WITA

Anugerah, Subur. 2020. Pengembangan Penelitian Tindakan Kelas Pemrograman Pada Kelas Virtual di Tengah Masa

Pandemihttps://www.researchgate.net/p ublication/342170027Pengembangan $P$ enelitian Tindakan Kelas Pemrograma n pada Kelas Virtual di Tengah Masa Pandemi, dibuka tanggal 15 Oktober 2020, pukul 13.35 WITA

Arikunto, Suharsimi. 2011. Penelitian Tindakan Untuk Guru, Kepala Sekolah \& Pengawas. Jakarta: Aditya Media.

Basir, Abdul. $1988 . \quad$ Evaluasi Pendidikan.Surabaya: Airlangga University Press.

Farhana, Karla. 2020. Memahami Arti Daring dan Luring, Cari Tahu Bedanya di Sini.https://www.fimela.com/lifestylerelationship/read/4304691/memahamiarti-daring-dan-luring-cari-tahu-bedanyadi-sini, dibuka pada tanggal 30 Oktober 2020 pukul 21.14 WITA

Fitra A. Sitorus M, Sinaga Dedi CP, Marpaung Endra A. P. 2020. Pemanfaatan dan pengelolaan Google Cclassroom sebagai media pembelajaran dan pengajaran daring bagi guru-guru SMP.Jurnal Pengabdi Vol.3 No. 2 , Oktober 2020 (p.101-109).

Gunawan, Fransiskus I dan Sunarman, Stefani G. 2017.Pengembangan kelas virtual dengan google classroom dalam keterampilan pemecahan masalah (problem solving) topik vektor pada siswa SMK untuk mendukung pembelajaran.Prosiding Seminar Nasional Etnomatnesia 2017 (hal. 340348)

Hapsari,Swita Amallia; Pamungkas, Heri. 2019. Pemanfaatan Google Classroom sebagai media pembelajaran online di Universitas Dian Nuswantoro.Wacana, Volume 18 No. 2, Desember 2019, hlm. $225-233$

Heri.Juli.4, 2020.MEDIA PEMBELAJARAN: Pengertian, Fungsi, Manfaat, Jenis Jenis \&

Contoh.https://salamadian.com/pengerti an-media-pembelajaran/ , dibuka tanggal 1 November 2020 pukul 11.21 WITA

Nenden E. 2015. (Jurnal Formatif 2(1): 10-22 ISSN: 2088-351X Nenden E. -

Peningkatan Hasil Belajar Biologi).https://media.neliti.com/media/p ublications/234841-peningkatan-hasilbelajar-biologi-dengan-7b304e40.pdf, dibuka tanggal 14 Oktober 2020 pukul 21.14 WITA

Nirfayanti dan Nurbaeti. 2019. Pengaruh media pembelajaran google classroom dalam pembelajaran analisis real terhadap motivasi belajar mahasiswa. Proximal: Jurnal Penelitian Matematika Dan Pendidikan Matematika. Volume 2 Nomor 1, Februari 2019 (hal 50-59).

Nova, Allert Benedicto I. 2018. Mengenal Sistem Organ pada Manusia dan Fungsinya.https://www.alodokter.com/m engenal-sistem-organ-pada-manusiadan-fungsinyal, dibuka tanggal 29 Oktober 2020 pukul 19.32 WITA

Salamah, Wiladatus..(2020). Deskripsi Penggunaan Aplikasi Google Classroom dalam Proses Pembelajaran.Jurnal Penelitian dan Pengembangan Pendidikan. Vol. 4 (3) pp. 533-538. 
Sevima, Admin. 2020. 6 Metode Pembelajaran Paling Efektif di Masa Pandemi Menurut Para Pakar. https://sevima.com/6-metodepembelajaran-paling-efektif-di-masapandemi-menurut-para-pakar/, dibuka tanggal 14 Oktober 2020 pukul 22.03

Soni, Hafid A, HayamiRegiolina, Fatma Y, Wenando FA, Al Amien J, FuadE, Unik M, Mukhtar H, dan Hasanuddin. 2018. Optimalisasi pemanfaatan google classroom sebagai media pembelajaran di SMK Negeri 1 Bangkinang.Jurnal Pengabdian Untuk Mu NegeRI, Vol.2 No.1, Mei 2018

Wicaksono, Vicky Dwi; Rachmadyanti, Putri. 2017. Pembelajaran blended learning melalui google classroom di sekolah dasar. Prosiding: Seminar Nasional Pendidikan PGSD UMS \& HDPGSDI Wilayah Jawa 2017 (513-521) 